\title{
THE COUNCIL OF EUROPE AND ITS MECHANISMS FOR PROTECTING AND GUARANTEEING HUMAN RIGHTS
}

\section{Tudor Tănăsescu}

\section{T. TĂNĂSESCU}

Faculty of Law

University "Bioterra” Bucharest, Romania

*Correspondence: Tudor Tănăsescu, str. Pescăruşului nr. 3, Bl. B-24, Sc.3, Et. 6, Ap. 145, Sector 2, Bucureşti, România.

E-mail: tanasescu.tudor@yahoo.com

\section{ABSTRACT}

The Council of Europe represents the main regional/European international intergovernmental organization in which the most efficient mechanisms for guaranteeing and protecting human rights have been initiated and developed.

The mechanisms implemented by this organization, aiming to protect and guarantee human rights, established through the conventional judicial tools adopted by the Council of Europe are: The European Court for Human Rights (jurisdictional mechanism), established by the European Convention on Human Rights, the conventional non-jurisdictional mechanisms for monitoring, as well as the system of regularly reporting and that of the collective complaints, employed by the European Committee for social rights, created based on the European Social Charter and its two protocols of 1991 and 1995, and the preventive control based on inquiries carried out by the European Committee for the Prevention of Torture and Inhuman or Degrading Treatment or Punishment, based on the European Convention of the Prevention of Torture.

Added to these some extra-conventional mechanisms are considered, such as The European Commission against racism and intolerance and The Commissioner for Human Rights at the Council of Europe.

KEYWORDS: COUNCIL OF EUROPE, PROTECTION MECHANISMS, GUARANTEEING, HUMAN RIGHTS.INTRODUCTION

\section{INTRODUCTION}

Generally, compared to the human rights protection system of the United Nations Organization, the mechanisms of the Council of Europe for protecting and guaranteeing human rights offer the image of a more integrated system, with additional possibilities of reparatory compensations in cases when violations of human rights have occurred ${ }^{1}$. While the UN system is very cautious in recognizing the possibility for willing states or individuals who had been prejudiced to question how some of the human rights are being implemented in practice, the European system takes further steps, establishing several procedures through which the states can be summoned and forced to provide explanations and, in the end, to execute certain verdicts that have ruled that human rights violations had taken place against their citizens. In such cases, the states can be forced/condemned to provide reparatory compensations and to adopt measures in order to reestablish the rights to the persons whose fundamental rights had been violated.

\footnotetext{
${ }^{1}$ Duculescu Victor, Legal protection of human rights, Publishing House Lumina Lex, Bucharest, 1994 p.94; Tănăsescu Tudor, International protection of human rights. University Course, Publishing House Sitech, Craiova, 2015, p.91; Scăunaş Stelian, International law of human rights. University Course, Publishing House All Beck, Bucharest 2003, p.54
} 
At first, the European system for protecting human rights enacted by the Convention on defending Human Rights and Fundamental Freedoms comprised three bodies: The European Commission of Human Rights, The European Court of Human Rights (jurisdictional mechanism) and The Committee of Ministers of the Council of Europe.

At the level of the Council of Europe, the judicial Control of the European Court of Human Rights is supplemented by other non-jurisdictional conventional mechanisms, such as the system enacted by the European Social Charter and its protocols, that imply the procedure of control carried out based on reports and the procedure of collective complaints ${ }^{2}$, or the preventive control based on inquiries carried out by the European Committee for the Prevention of Torture and of other Inhuman or Degrading Treatment or Punishment, enacted through the European Convention of the Prevention of Torture and of other inhuman or degrading punishment or treatment, in 1987. At the same time, some extra-conventional mechanisms can be noticed, such as the European Commission against racism and intolerance or The Commissioner for Human Rights at the Council of Europe.

According to Art.20 of the European Convention on Human Rights ${ }^{3}$, The European Commission on Human Rights was made up of a number of individually elected members equal to that of the Convention's member states. The members of the Commission were elected by The Committee of Ministers of the Council of Europe, based on a list drawn by the Bureau of the Parliamentary Assembly. The mandate of the Commission lasted 6 years and its headquarters was in Strasbourg. The Commission elected its president and its two vice-presidents for a three-year mandate.

The Commission could be notified through requests, forwarded to the General Secretary of the Council of Europe by private individuals, natural or juridical persons, regarding supposedly violations of the Convention's provisions.

The Commission worked in plenary sessions or in chambers of seven members each or in committees made up of at least three members. The Commission could verdict the following:

- $\quad$ turn down the request;

- $\quad$ accept the request, followed by drawing up a report, should an amiable solution was reached in the case. The report was forwarded to the interested involved states, The Committee of Ministers and the Secretary General of the Council of Europe, in order to be released;

- should no solution be reached, a report comprising possible deemed proposals would be drawn up and sent to The Committee of Ministers and the interested states, without the possibility of being released;

- $\quad$ should the case be sent to the European Court of Human Rights in 3 months' term from forwarding its report to The Committee of Ministers, the latter would decide whether there had or hadn't been a violation of the Convention and, if affirmative, would set a deadline up to when the involved state should implement the measures drawn by the decision of the Committee of Ministers.

In the initial form set by the Convention, The European Court on Human Rights could be notified, after the Commission had taken notice of the failure of an amiable solution, in three month's term, by the Commission, the state whose citizen is the victim, the state that had notified the Commission, the state involved in the case or by the private individuals, natural or juridical persons, who had notified the Commission.

Therefore, the Commission worked as a "filter" of access to the European Court on Human Rights, which made this mechanism of receiving and evaluating notifications to work

\footnotetext{
${ }^{2}$ Miga-Beşteliu Raluca and colab., International protection of human rights. Courses notes, Edited by S.C. Universul Juridic, Bucharest, 2008, p. 270

${ }^{3}$ Text, in Vida Ioan, Human rights in international regulations, Publishing House Lumina Lex, Bucharest 1999, p.289
} 
difficultly $^{4}$. This is the reason why the additional Protocol no.11 to the European Convention on Human Rights for reforming the Convention's prior control mechanism ${ }^{5}$ was adopted in Strasbourg in 1994, aiming at increasing efficiency in defending fundamental human rights and freedoms. Basically, the initial control mechanism has been simplified through the joining of the Commission and the European Court on Human Rights and by the establishment of a Single Court - The European Court on Human Rights, an institution with a jurisdictional and permanent character.

The Commission continued to exist, according to Protocol no.11, till 31.10.1999, and it took care of the admitted cases, until the enactment of the Protocol.

The Committee of Ministers is a decision making body of the Council of Europe, which organizes intergovernmental cooperation in the fields of interest for the organization. It comprises ministers of foreign affairs from the member states. The Committee can adopt agreements and conventions with mandatory judicial sentencing for the states which had ratified these regulations. This body also observes how the member states comply to the proclaimed human rights standards. The Committee can request consultative vetting from the European Court on Human Rights, on certain legal aspects pertaining to the interpretation of the European Convention on Human Rights and its Protocols. This body is also tasked with monitoring how the states implement the verdicts of the European Court for Human Rights.

\section{CONSIDERATIONS ON THE MECHANISMS OF THE COUNCIL OF EUROPE FOR PROTECTING AND GUARANTEEING HUMAN RIGHTS}

\section{A. Jurisdictional mechanisms}

1. The European Court on Human Rights.

General view on the organizational structure of the European Court on Human Rights

The present European Court on Human Rights (henceforth referred to as The Court) was first established by the European Convention on human rights and its current form was set through the additional Protocol no.11 to the mentioned Convention, signed in Strasbourg, on May 11, 1994.

The Court comprises a number of judges equal to that of the member states of the Convention (also members of the Council of Europe, at present 47 members), serving an individual mandate. They are elected by the Parliamentary Assembly of the Council of Europe, with a majority of votes, from among the candidates proposed by each state.

The judges are elected for a six-year term, with the possibility of being reelected. On the first election, half of the number of judges will end their term after three years, aiming to renewing half of the term every 3 years ${ }^{6}$. In order to insure this renewing, the Parliamentary Assembly can decide, before proceeding to another election, if one or more mandates may last more or less that 6 years, without dropping under 3 years or extending more than 9 years.

When a judge is elected to replace a judge whose mandate isn't over yet, he must see to his predecessor's mandate.

When turning 70 years of age, the judge's mandate ends, but the judges always hold their seats until their replacement and continue to see to solve the cases that they had been noticed about.

Should a judge find himself in the impossibility of fulfilling his tasks or cannot be anymore notified, the member state that had initially recommended him is invited to propose

\footnotetext{
${ }^{4}$ The number of requests addressed to the Commission after 1990 made more difficult settlement procedures. If in 1993 the Commission registered 2,037 cases in 1997 the number of cases has risen to 47,050.

${ }^{5}$ Adopted on 11 May 1994 and entered intor force on 01.11.1998. Romania has ratified the Protocol by Law No.79 of 6 July 1995, Official Gazette no.147/1995

${ }^{6}$ Protocol No.11 to the European Convention on Human Rights and Fundamental Freedoms, art.23. Vida Ioan text op.cit., p.333
} 
another judge in 30 days, to nominate another elected judge or propose, as ad-hoc judge, someone else suitable to the position of an elected judge.

The judges elect the president, one or two vice-presidents and two section presidents.

Revoking a judge from his position needs a majority of two thirds of the number of judges.

The Court is organized on two categories of structures/sections - administrative and jurisdictional. The administrative structures are:

- The Plenary Assemble of the Court, led by two presidents and one or two vicepresidents;

- The sections led by their presidents.

The jurisdictional structures are:

- The Committees,

- The Chambers; and

- The Grand Chamber.

Added to these three, the Single judge was to be introduced following the enactment of the Protocol no. 14.

The Court works in assemblies, examining the cases brought forth in Committees, Chambers and the Grand Chamber.

The Plenary Assembly of the Court comprises all the elected judges; it has an administrative role.

The President of the Court ${ }^{7}$ leads the activity of the Court, represents the Court and assures its relationships with the Council of Europe. He chairs the Plenary Assembly, the sittings of the Grand Chamber and those of the College of the Grand Chamber.

The Vice-president or the vice-presidents of the Court ${ }^{8}$ assists the president of the Court and sit in for him on his request or whenever he takes a leave. They are also the presidents of the sections.

The Sections ${ }^{9}$, five at number, represent administrative departments of the Court, established by the Plenary Assembly, for a three-year term. Each judge is a member of one of the Sections. The structure of the sections must be balanced in terms of judicial and gender representing. Each section has a president, while two of the five presidents of the sections are also vice-presidents for the Court.

The presidents of the sections ${ }^{10}$ are elected by the Plenary Assembly for a three-year term, which can be renewed. They chair the sittings of the section and of the Chamber whose members they are.

The location of the Court is in Strasbourg, also hosting the Council of Europe, but, when necessary, the Court can act in various locations on the territory of the member states of the Council of Europe ${ }^{11}$.

As mentioned above, for examining the cases brought forth, the Court works in Committees, Chambers and the Grand Chamber.

The Committees ${ }^{12}$ are formed by three judges from the same section, for an established period of 12 months. Each committee is chaired by the main judge of the section. A Committee can declare an individual request, based on an unanimously vote, as unacceptable or can rule it out, when such a decision can be taken without the need of complementary examination, this being the final verdict. The committees can't rule in cases between states.

\footnotetext{
${ }^{7}$ Regulation..., document cit., art.9

${ }^{8}$ Ibidem, art.10.

${ }^{9}$ Ibidem, art. 25 .

${ }^{10}$ Ibidem, art.12.

${ }^{11}$ Ibidem, art.19.

12 Ibidem, art.27.
} 
The seven-judge chambers ${ }^{13}$. For each case, the chamber comprises the president of the section and the rightfully judge, elected on behalf of a state involved in the case (the national judge). The elected judge can be replaced by an ad-hoc judge. The chambers can rule on the acceptance of the case, as well as on the matter of the individual requests, should the Committee doesn't rule them as unacceptable or doesn't dismisses them from the Court, as well as on the acceptance and the basis of the requests put forth by the states.

The Grand Chamber ${ }^{14}$ is formed by 17 judges and 3 deputy judges, for a three-year term. Part of the Grand Chamber are compulsory the president and the vice-presidents of the Court, the presidents of the Chambers and other judges nominated according to the Regulation of the Court, as well as, as rightful member, the judge elected on behalf of the stated involved in solving the differences. The Grand Chamber rules on the individual requests or on the cases between states when the case had been deferred to it by a Chamber, as effect of its declining of competency or in case of remittance by any of the parties, in three month's term from the ruling of the Chamber.

The Clerk of the Court ${ }^{15}$. In its activity, the Court is assisted by a body of clerks, led by the Clerk of the Court, elected through secret vote, with an absolute majority, by the Plenary Assembly, from among the candidates with a high moral profile, holding the required judicial, administrative and linguistic knowledge in order to work as court clerk. The election is for a five-year term, with the possibility of renewal.

The Clerk of the Court is assisted in his work by two deputy court clerks.

The Clerk has the following tasks:

- $\quad$ assists the Court in its work;

- $\quad$ is in charge of organizing the records and the activities of the body of court clerks;

- insures the security of the archives and intermediates communications and the notifications forwarded or issued to/by the Court;

- $\quad$ answers the requests of information with regard to the Court's activity, especially those coming from the press, while respecting the rules of confidentiality.

The body of court clerks works according to the general regulations established by the Clerk and approved by the president of the Court.

The body of court clerks comprises the sections' bodies of court clerks, equal as number with the number of the sections of the Court, and the administrative and juridical services that the Court requires in its activity.

The Court rules ${ }^{16}$ inside the council room, secretly, and only the judges take part in the ruling, along with the court clerk, other agents of the court clerk body and interpreters, according to the situation. Before voting, the judges of the Court must express their opinion.

The rulings of the Court are backed by a majority of votes from the judges who are present.

The decisions and the verdicts of the Grand Chamber and the Chambers are adopted with a majority of the votes of the judges who are present and no refraining is allowed in matters pertaining to the acceptance or the basis of the case. ${ }^{17}$

The decision of the Grand Chamber is final and that of a Chamber becomes final should the parties declare that they will not request the forwarding of the case to the Grand Chamber or will not have it forwarded in three year's term from the ruling or in the case when the Grand Chamber doesn't approve resending the request.

The final verdict of the Court is conveyed to the Committee of Ministers, which supervises its implementation. The consultative vetting of the Court in judicial matters

\footnotetext{
${ }^{13}$ European Convention on Human Rights, Vaida Ioan text, Human rights and international regulatiuons, op.cit., art.27, par.1.

14 Ibidem, art.24.

${ }^{15}$ Regulation..., doc.cit., art.15, 17 and 18

${ }^{16}$ Ibidem, art.22.

${ }^{17}$ Ibidem, art.23.
} 
regarding the interpretation of the Convention can be released only upon the request of the Committee of Ministers.

The competence of the European Court on Human Rights.

The competence of the Court comprises all the issues pertaining to the interpretation and the enactment of the Convention and of its Protocols, as follows ${ }^{18}$ :

- $\quad$ any member state may notify the Court over any violation of the provisions of the Convention and its Protocols that another member state may have reportedly committed (cases between states) ${ }^{19}$;

- by notification in a request coming from any individual, any $N G O$ or any private group claiming to be victims of the violations of the rights acknowledged by the Convention or its Protocols (individual requests) committed by any signatory state. This right can't be hindered in any way by the signatory states ${ }^{20}$;

- the Court can offer consultative vetting, at the request of the Committee of Ministers of the Council of Europe, on judicial matters regarding the interpretation of the Convention and its Protocols ${ }^{21}$.

The individual complaints have led to an over burdening of the European Court and, in the context, to a lack of efficiency in its activity, because the system conceived by the Protocol no. 11 hadn't had in view the notifying of the Court by such a large number of petitioners $^{22}$.

Under the circumstances, the Protocol no. 14 attempts to increase the efficiency of the control system by rethinking the modus operandi of the control mechanism.

Thus, through this document (Protocol no. 14) a new jurisdictional institution is established - the single judge - who adds up to the Committees, the Chambers, the College of the Grand Chamber and the Grand Chamber. The single judge will take over the tasks of filtering the individual requests from the Committees and can declare them as inadmissible. The Committees are extending their competence and can examine individual requests on the matter, should the interpretation or the applying of the European Convention or of the Protocols is object to an established jurisprudence of the European Court. Protocol no. 14 also introduces a new special condition of admittance, namely it is requested the complainant to have suffered an important damage as effect of the reportedly human rights violation, excepting the case when respecting the human rights imposes an examination of the matter of the cause or when the cause of the complainant hadn't been properly examined by a national court.

The additional Protocol no. 14, was enacted following its ratifying by all the member states of the Convention for defending human rights and fundamental freedoms (in 2008, out of the 47 member states 46 had ratified it).

The languages in which the verdicts are written are English and French, except for when it is decided that other official languages must be used.

The verdicts are signed by the president of the Court and by the court clerk, are read in open sitting by the president or by a judge assigned by the president and are conveyed to the Committee of the Ministers, to the parties involved, to the Secretary General of the Council of Europe, to third intervenient parties and to any other directly interested person ${ }^{23}$.

\footnotetext{
${ }^{18}$ European Convention on Human Rights, doc.cit., art.32

${ }^{19}$ Ibidem, art.33.

${ }^{20}$ Ibidem, art.34.

${ }^{21}$ Ibidem, art.47.

${ }^{22}$ Vezi Miga-Beşteliu Raluca and colab., op.cit., p.264

${ }^{23}$ Regulation doc. cit., art.77.
} 
The final verdicts of the Court are released under the authority of the court clerk, who is also in charge of releasing the official compendium of the Court's verdicts and decisions.

The parties involved in the case solved by the Court can request, in one year's term, the interpretation of a verdict. Should the request be accepted the parties are invited to present written objections and to present them in front of the chamber, who decides through a verdict $^{24}$.

Upon the request of the party that had put forth a petition or upon appointment, the president of the chamber can offer judicial assistance for the defending of the cause. If this assistance is offered, the petitioner will also benefit of it in front of the Grand Chamber ${ }^{25}$.

The judicial assistance can't be provided unless it is necessary for the proper development of the cause and unless the petitioner doesn't have sufficient financial means in order to totally or partially support the costs implied by the sustaining of his cause ${ }^{26}$.

In order to establish if the petitioner holds or not sufficient financial means, he will fill in a declaration indicating his resources, valued goods, financial obligations towards persons who are in his custody and any other financial obligation ${ }^{27}$. This declaration will be certified by the internal competent authority or authorities. At the same time, the member state involved is invited to present its written observations. Following this procedure, the president of the chamber decides on admitting or refusing the judicial assistance and the court clerk will inform the interested parties.

Upon the request of The Committee of Ministers of the Council of Europe, the Court can offer consultative vetting on judicial problems regarding the interpretation of the Convention and its Protocols ${ }^{28}$.

The Convention makes clear the fact that this vetting can't refer to issues concerning the content or the extending of the rights and liberties provided by it and its Protocols or to matters that might be acknowledged as effect of making an appeal according to the Convention.

The consultative vetting, as well as the Court's verdict considering that the vetting is not in its competence, is signed by the president of the Court and by the court clerk and is filed to the Court's archives and then is conveyed in legalized/certified copies to the Committee of Ministers, to the involved member states and to the Secretary General of the Council of Europe ${ }^{29}$.

The Revised European Social Charter replaces, for its member states, the European Social Charter and its protocols.

\section{B. The non-jurisdictional European control mechanisms}

1. The control mechanisms introduced by the European Social Charter and its two protocols of 1991 and 1995.

The additional Protocol of 1995, establishing a system of collective complaints, has also continued to be applied to the Revised European Social Charter as an additional protocol.

- In order that the member states respect the provisions of the European Social Charter and of the Revised European Social Charter, a control mechanism had been established, implying two control procedures: the control procedure based on reports and the procedure of collective complaints.

The control procedure based on reports

\footnotetext{
${ }^{24}$ Ibidem, art.79.

${ }^{25}$ Ibidem, art.91.

${ }^{26}$ Ibidem, art.92.

${ }^{27}$ Ibidem, art.93.

${ }^{28}$ Convention..., doc.cit., art.47.

${ }^{29}$ Regulation..,doc.cit., art.90.
} 
Through the protocol of amending the Charter in 1991 a Committee of Independent Experts was established (which replaces, upon the request of the Committee of Ministers, the Committee of experts), having 9 members elected by the Parliamentary Assembly of the Council of Europe on a six-year term, from a list of experts proposed by the member states. The members carry out their mandate individually, in total independence. The control procedure implies the obligation that the member states present a report on the implementing of the accepted Charter's provisions (Part II) twice a year. At certain times and upon the request of the Committee of Ministers, the member states also present reports to the Secretary General of the Council of Europe on the provisions of the Charter that they didn't accept, either upon ratification or later on. The state reports are examined by the Committee of Independent Experts. Following the examination, the reports and the observations of the Committee of Independent Experts are sent to a Governmental Committee that had also been established based on the Protocol for amending the Charter, as a body which replaces the Subcommittee of the Governmental Social Committee. Based on the reports and observations of the Committee of Independent Experts, as well as on the comments of the invited observatories, The Governmental Committee, comprising a representative of each member state (the Revised European Social Charter), prepares the resolutions and recommendations for the Committee of Ministers of the Council of Europe regarding the situations noticed in the states' practices, including those related to the violation of the assumed obligations.

At present, the Committee of Independent Experts is denominated as the European Committee of Social Rights ${ }^{30}$.

The procedure of collective complaints.

It was introduced by the additional Protocol to the European Social Charter in 1995 and came into act in 1998.

According to art. 1 of the Protocol of 1995, the following entities are entitled to make collective complaints regarding the violations of the provisions of the European Social Charter and of the Protocol of 1995, namely of the Revised European Social Charter:

- international business organizations and organizations of employees invited at the reunions of the Government Committee;

- other international non-governmental organizations having consultative status to the Council of Europe;

- $\quad$ representative national organizations of employers and employees.

The procedure has two phases, that of examining the admittance of the complaint, resulting in a decision regarding the admittance, and the phase of the examination of the matter.

The complaint must be forwarded in written form and will comprise the data which is necessary for identifying certain improper implementations of the Charter. The complaint forwarded to the Secretary General of the Council of Europe will be sent to the Committee of Independent Experts.

The member state against which the complaint is formulated will be informed.

Should the complaint is admitted, the Committee will inform the member states of the Charter and request the state involved and the petitioning organization to make observations on the matter.

The Committee of Independent Experts draws a report comprising its conclusions on the invoked base of the petition; the report is sent to the Committee of Ministers and is communicated to the petitioner and to the member states, with no possibility of release.

Based on the report of the Committee, the Committee of Ministers adopts a resolution or, a recommendation, should it notices an improper implementing of the Charter. The

\footnotetext{
${ }^{30}$ Vezi Miga-Beşteliu Raluca and colab., op. cit., p.273
} 
document issued by the Committee of Ministers, along with the report of the Committee of Independent Experts, can be released by the Parliamentary Assembly.

2. The preventive mechanism used by the European Committee for the prevention of torture and of other inhuman or degrading treatment or punishment. The Committee was designed as a body with competence in assessing the treatment of detainees, in order to insure increased protection against bad treatment, by carrying out inspections ${ }^{31}$. In fulfilling its mission, the Committee cooperates with the assigned national authorities of the member states of the European Convention for the prevention of torture and of other inhuman or degrading treatment or punishment.

The Committee for preventing torture comprises a number of members equal to that of the member states of the Convention (47 at present), chosen from among the personalities with a high moral profile, known for their competence in the field of human rights. The members are elected for a four-year term, with the possibility of being two more times reelected with an absolute majority by the Committee of Ministers of the Council of Europe. Each state proposes three candidates. The sessions are confidential.

The monitoring mechanism used by the Committee is based on the inspections carried out by at least two members of the Committee in the member states. The intention of the Committee of making an inspection call must be notified to the government of the state involved.

The Committee can have free discussions, with no witnesses, with the detainees.

The results of the inspections can be conveyed to the Committee, either directly, on the spot, to the assigned national authorities or through a report drawn by the Committee following each inspection. The report comprises the findings, taking into consideration all the observations made by the member state. The report is sent to the member state along with the recommendations that the Committee deems as necessary. The Committee can suggest an improvement of the conditions of the detainees.

If the member state refuses to cooperate or to enhance the situation of the detainees in concurrence with the recommendations of the Committee, the latter can decide, with a majority of two thirds of its members, to issue a public declaration on the matter.

Annually, the Committee presents to the Committee of Ministers a general report of its activities, respecting the requirements of confidentiality.

\section{THE EUROPEAN COMMISSION AGAINST RACISM AND INTOLERANCE}

It was created following the summit in Vienna in 1993, the first high-level reunion of the state and government leaders of the member states of the Council of Europe. In 2002, the Committee of Ministers of the Council of Europe adopted a new statute for this Commission. According to the new statute, the Commission has the following main tasks:

- to examine the legislations, the policies and the other measures taken by the member states aiming at countering racism, xenophobia, anti-Semitism and intolerance, as well as their effects;

- to study the international pertaining judicial tools in the field, with the aim of consolidating them.

The Commission monitors within a control framework all the member states in matters pertaining to the racism, xenophobic, anti-Semitic and intolerance phenomena and draws reports with analyses of the state of facts and the optimal proposals to solving the identified problems.

The Commissioner for human rights. The institution of the Commissioner for human rights was established by the Resolution (99) 50 of the Committee of Ministers of the

\footnotetext{
${ }^{31}$ Vezi Miga-Beşteliu Raluca and colab., op.cit., p.285-289; Niciu Marţian, Public International Law, Publishing House Servosat, Arad, 2004, p.218-220.
} 
Council of Europe on May 7, 1999. According to the resolution, the Commissioner is a nonjurisdictional institution, designed to promote education, knowledge and respect for human rights in the member states of the Council of Europe, as they are stipulated by the judicial instruments of this international organization.

The person who occupies this position is elected by the Parliamentary Assembly, with a majority of votes, from a list of three candidates drawn up by the Committee of Misters. The candidates can be proposed by the member states and must hold the citizenship of one of these states. The mandate of the Commissioner is six years, without any renewal.

Among the tasks of the Commissioner, as stipulated in art.3 of the Resolution (99) 50, we highlight:

- promoting education and knowledge of human rights in member states;

- contributes to promoting genuine respect towards human rights in member states;

- gives advice and information about protecting human rights and preventing their violation;

- facilitates the activities of national ombudsmen or of the similar human rights institutions;

- identifies possible deficiencies or non-concordances in the laws or the practices of the member states, pertaining to respecting human rights;

Whenever he deems necessary, the Commissioner can write reports on certain issues in his tasked field of activity and have them forwarded to the Committee of Ministers or the Parliamentary Assembly and the Committee of Ministers. The Commissioner also presents a yearly general report to the Committee of Ministers and the Parliamentary Assembly.

The member states are obliged to facilitate the independent and effective activity of the Commissioner in fulfilling his tasks, especially pertaining to his contacts when gathering relevant data. The Commissioner can make direct contact with the governments of the member states of the Council of Europe.

The documents of the Commissioner for Human Rights are: the recommendations, the opinions and the reports. The Committee of Ministers can authorize the release of any recommendation, opinion or report it receives.

Within the framework of the activities carried out by the Commissioner, organizing seminars and conferences with the aim of promoting education and maintain the relationship with other structures and organizations involved with human rights must be mentioned.

\section{CONCLUSIONS}

- The Council of Europe represents the institutional framework in which the most efficient mechanisms for protecting and guaranteeing human rights have been initiated and developed.

- Referred to their tasks, the mechanisms of the Council of Europe, have either jurisdictional roles (e.g. The European Court on Human Rights) or recommendation/advisory roles, with no judicial power towards the member states. They have regional competence and are developed in close relation with those belonging to the United Nations.

- The Mechanisms of the Council of Europe pertaining to human rights are represented by: The European Court on Human Rights, The European Committee for Social Rights, The European Committee for the Prevention of Torture and of other Inhuman and Degrading Treatment, The European Commission against racism and intolerance and the Commissioner for Human Rights of the Council of Europe.

- The Mechanisms of the Council of Europe for the protection and guaranteeing of human rights created, mainly by conventional judicial tools adopted by this organization, use practices (solicitor's procedures and consultative vetting, regularly reporting, complaints, preventive control, etc.) based on which the states can be summoned and obliged to explain, 
and, in the end, abide to recommendations or execute certain verdicts that have identified human rights violations against their citizens. In such cases, they can be obliged/sentenced to offer reparatory compensation and take measures towards reestablishing the rights of the individuals whose fundamental rights had been violated.

\section{BIBLIOGRAPHY}

1. Beşteliu Raluca Miga and colab. International protection of human rights. Courses notes, Publishing House S.C. Universul Juridic, Bucharest, 2008;

2. Duculescu Victor, Legal protection of human rights, Publishing House Lumina Lex, Bucharest, 1994;

3. Niciu Marţian, Public International Law, Publishing House Servosat, Arad, 2004

4. Scăunaş Stelian, International law of human rights. University Course, Publishing House All Beck, Bucharest, 2003;

5. Tănăsescu Tudor, International protection of human rights. University Course, Publishing House Sitech, Craiova 2015;

6. Vida Ioan, Human rights in international regulations, Publishing House Lumina Lex, Bucharest 1999. 